\title{
ESTIMATING THE INTERNAL FORCES OF RAFT IN PILED RAFT FOUNDATION FOR NORMAL AND GROUNDWATER PUMPING CONDITIONS: A CASE STUDY SOC TRANG PROVINCE, VIETNAM
}

\author{
Huynh Van Hiep ${ }^{1}$, Huynh Huu Tri ${ }^{2}$, Ngo Gia Truyen ${ }^{3}$, Tran Van Tuan ${ }^{4}$
}

\begin{abstract}
Piled raft foundations are widely used in infrastructure built on soft soil to reduce the settlement and enhance bearing capacity. The raft can be used for basements and to share the load. In this paper, Poulos method, in which the raft was cut into many piled strips, was used as an analytical method. The study also used Plaxis $2 D$ and SAP 2000 to calculate internal forces for the raft in a piled raft foundation. A case of Vietcombank building with 10 floors and 1 basement, constructed on a soil profile in Soc Trang province, was studied. The piled raft with a $35 m \times 19 m \times 1 m$ (length $\times$ width $\times$ thickness) $r a f t$ and 28 piles were used for the analysis. Normal and groundwater pumping conditions were applied for the soil. The results showed that the maximum moment and shear force that occurred in the raft were affected when the groundwater pumping condition was applied to the model. The internal forces of the raft in the piled raft foundation for different conditions were captured, discussed, and presented in this paper.
\end{abstract}

Keywords: groundwater pumping, internal forces, piled raft, Poulos method.

\section{INTRODUCTION}

In the Mekong Delta, shared by various countries, predominantly Cambodia and Vietnam, groundwater exploitation has increased dramatically in recent decades. Up from a limited number before the 1960s, today more than one million wells access groundwater for domestic, agricultural, and industrial needs, causing hydraulic heads (i.e., groundwater levels) to steadily

\footnotetext{
${ }^{1,2,3}$ School of Engineering and Technology, Tra Vinh University

${ }^{4}$ Can Tho University

Email: huynhtri@tvu.edu.vn

Received date: $29^{t h}$ January 2020; Revised date: $29^{\text {th }}$ October 2020; Accepted date: $20^{t h}$ December 2020
}

decline in many aquifers over extensive regions [1]. Monitoring wells indicate a drop of over $15 \mathrm{~m}$ at $\mathrm{Ca} \mathrm{Mau}$, Viet Nam, since the mid-1990s, leading to a cone of depression now nearly $20 \mathrm{~m}$ below sea level datum. The current rate of hydraulic head decline among Delta wells averages $26 \mathrm{~cm} / \mathrm{yr}$ (range: $9 \div 78 \mathrm{~cm} / \mathrm{yr}$ ), which has caused widespread regional drawdown in approximately a $100 \mathrm{~km}$ wide swath trending NE from Ca Mau towards Ho Chi Minh City. The magnitude of drawdown diminishes in wells with increasing proximity to the international border, owing to minimal groundwater extraction in Cambodia, reduced development density in northeastern areas of the Vietnamese Delta adjacent to Cambodia, and bedrock outcropping in the Northwestern corner of the Delta [2].

There are three principal foundation options for high-rise buildings: 1) Raft foundations, where the loads are transferred to the ground via a foundation raft; 2) Pile foundations, where the loads are transferred to a deeper load-bearing layers via piles or diaphragm wall elements; and 3) Pile and raft foundations (PRF), where the high-rise load is taken partly by the raft and partly by the piles or diaphragm wall [3].

Nowadays, piled raft foundation is widely used for the design of foundations of medium and high rise buildings. This type of foundation is applied as an optimal solution for structures as well as construction costs [4]. In practice, the piled raft foundations are usually designed with total load which is carried by the piles [5], [6]. However, the contribution of the raft is often overlooked, even when the bottom of the raft makes contact with the ground. The drawdown of the water table profoundly influences the settlement and load sharing capacity of piled raft foundations. On the other hand, estimating the internal forces (moment and shear forces) of rafts in a piled raft 
foundation for normal and groundwater pumping conditions is very important for the structural design of the raft. Poulos [7] presented an analytical method for calculating internal forces of the raft in a piled raft foundation by dividing the raft into strips. In the preliminary calculation stage, the method was found to be suitable for estimating the internal forces of the raft in a piled raft foundation on soil data of Soc Trang Province in this study. Plaxis software [8] and SAP 2000 software [9] is also a strong finite element method for analyzing internal forces of a raft in a piled raft foundation.

This paper was focused on estimating the internal forces of a raft in a piled raft foundation for normal and groundwater pumping conditions. The soil data in Soc Trang Province of Viet Nam was considered for this research. Poulos method [7] and finite element method (FEM) were used in the analysis.

\section{METHODOLOGY}

Das [10] presented that the stress distribution in the soil below the foundation depends on the stiffness of the raft and soil type as shown in Figure 1. Therefore, when designing a rigid foundation on a clay layer at the surface, as in Soc Trang Province, the stress distribution under the foundation has its maximum value at the center of the foundation. In this study, stress distribution under the foundation, taken for calculation of the internal forces of the raft, was an average value (Figure 1).

The load sharing by the group of piles as well as each pile in the piled raft foundation was calculated by the method presented in Poulos [6]. In this study, piled load share was chosen about $75 \%$ the total load of the foundation. Then, loads at the top of piles were used as a solution for the internal force of the raft. The external loads on the raft were the working load of the basement and superstructural load. The external loads (concentrate and distribution loads) were changed into distribution loads by dividing the total load to the area of the raft.

Finally, the internal forces of the raft in the piled raft foundation were determined based on Plaxis [8] and SAP software [9]. A worksheet by

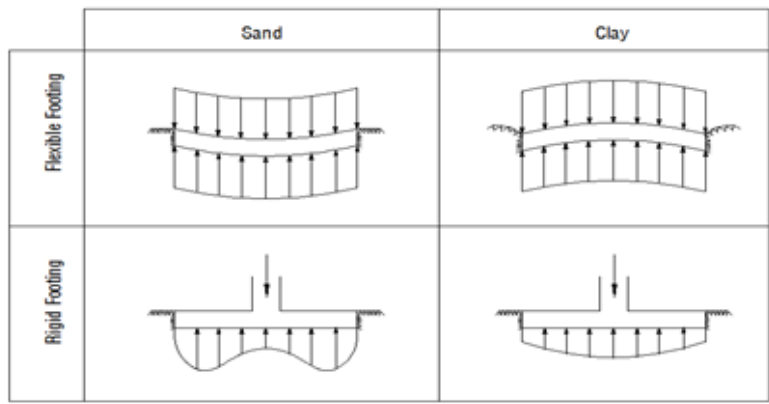

Fig. 1: Distribution of stress under the foundation in different soils [10]

Excel was also used for the calculation of internal forces of the raft. Results of the analyses were presented in diagrams.

Soil stress qult exerted on the raft was determined by the formula:

$q_{u l t}=c x N_{c} \times F_{c s} \times F_{c d} \times F_{c i}+q \times N_{q} \times F_{q s} \times$ $F_{q s} \times F_{q d} \times F_{q i}+0.5 \times \gamma \times B \times N_{\gamma} \times F_{\gamma s} \times$ $F_{\gamma d} \times F_{\gamma i}\left(M N / m^{2}\right)$

The total bearing capacity of the raft $\left(q_{u l t}\right)$ was calculated as

$$
Q_{\text {raft }}^{\text {ult }}=q_{u l t} \times A(M N)
$$

Where A was the total area of the raft $\left(m^{2}\right)$.

\section{CASE STUDY}

The design method is illustrated for a hypothetical soil profile and the building. Soil properties were taken from Soc Trang, and the building was chosen, Vietcombank building (branch in Soc Trang Province). Table 2 and Table 3 show the summary of soil properties and loading data of the case study, respectively. (The building is located at number 3, Tran Hung Dao Street, Ward 1, Soc Trang City, Soc Trang Province, Viet Nam).

\section{A. Calculation of the raft}

A raft with the dimensions of $35 \mathrm{~m} \times 19 \mathrm{~m} \times 1 \mathrm{~m}$ (length $\times$ width $\times$ thickness) was considered. The stress, at the bottom of the raft, in an undrained condition was, based on equations (1) and (2) respectively, about $49.13 \mathrm{kN} / \mathrm{m}^{2}$, and the total ultimate bearing capacity of the raft was about $30.14 \mathrm{MN}$. 
Table 1: The coefficient of shape, depth, declination of the foundation below the ground [10]

\begin{tabular}{|c|c|c|}
\hline Coefficient & Relative & Resources \\
\hline Shape & $\begin{array}{c}\mathrm{F}_{\mathrm{cs}}=1+\frac{\mathrm{BN}_{q}}{\mathrm{LN}_{\mathrm{c}}}, \mathrm{F}_{q s}=1+\frac{\mathrm{B}}{\mathrm{L}} \tan \varphi, \mathrm{F}_{\gamma \mathrm{s}}=1-0.4 \frac{\mathrm{B}}{\mathrm{L}} \\
\text { where } \mathrm{L}=\text { length of raft }(\mathrm{L}>\mathrm{B})\end{array}$ & [11] \\
\hline Depth & $\begin{array}{c}\text { Condition (a): } \frac{D_{f}}{B} \leq 1 \\
F_{c d}=1+0.4 \frac{D_{f}}{B}, F_{q d}=1+2 \tan \varphi(1-\sin \varphi)^{2} \frac{D_{f}}{B}, F_{y d}=1 \\
\text { Condition (b): } \frac{D_{f}}{B}>1 \\
F_{c d}=1+0.4 \tan ^{-1}\left(\frac{D_{f}}{B}\right), F_{q d}=1+2 \tan \varphi(1-\sin \varphi)^{2} \tan ^{-1}\left(\frac{D_{f}}{B}\right), F_{y d}=1\end{array}$ & \\
\hline Declination & $\begin{array}{l}\qquad \mathrm{F}_{\mathrm{ci}}=\mathrm{F}_{\mathrm{qi}}=\left(1-\frac{\beta^{0}}{90^{0}}\right)^{2}, \mathrm{~F}_{\mathrm{yi}}=\left(1-\frac{\beta^{0}}{\varphi^{0}}\right)^{2} \\
\text { where } \beta^{0}=\text { declination of load with vertical }\end{array}$ & {$[12],[13]$} \\
\hline \multicolumn{3}{|c|}{$\begin{array}{l}\text { These factors shape the empirical relationship based on experiments expand } \\
\qquad \tan ^{-1}\left(\frac{D_{f}}{B}\right)\end{array}$} \\
\hline
\end{tabular}

Table 2: Summary of soil properties [14]

\begin{tabular}{|c|c|c|c|c|c|c|c|c|c|c|c|}
\hline $\begin{array}{c}\text { Soil } \\
\text { layer }\end{array}$ & $\begin{array}{c}\text { Thickness } \\
\mathbf{( m )}\end{array}$ & $\begin{array}{c}\mathrm{c} \\
\left(\mathbf{k G} / \mathbf{c m}^{\mathbf{2}}\right)\end{array}$ & $\begin{array}{c}\varphi \\
(\mathbf{D e g r e e})\end{array}$ & $\begin{array}{c}\gamma \\
\left(\mathbf{T} / \mathbf{m}^{\mathbf{3}}\right)\end{array}$ & $\begin{array}{c}\gamma_{\mathrm{d}} \\
\left(\mathbf{T} / \mathbf{m}^{\mathbf{3}}\right)\end{array}$ & $\begin{array}{c}\gamma_{\mathrm{b}} \\
\left(\mathbf{T} / \mathbf{m}^{\mathbf{3}}\right)\end{array}$ & $\begin{array}{c}\text { Water } \\
\mathbf{c o n t e n t} \\
\mathbf{W} \mathbf{( \% )}\end{array}$ & $\begin{array}{c}\text { Densit } \\
\mathbf{y}\end{array}$ & $\begin{array}{c}\text { Void } \\
\text { ratio } \\
\mathbf{e}\end{array}$ & $\begin{array}{c}\text { Degree of } \\
\text { Saturation } \\
\mathbf{G}\end{array}$ & $\begin{array}{c}\text { Liquid } \\
\mathbf{\text { index }} \\
\mathbf{B}\end{array}$ \\
\hline $\mathrm{CL} 1$ & 13.4 & 0.035 & 2.19 & 1.518 & 0.871 & 0.544 & 74.33 & 2.66 & 2.06 & 97.70 & 2.51 \\
\hline $\mathrm{CL} 2$ & 2.8 & 0.082 & 3.49 & 1.635 & 1.041 & 0.651 & 57.06 & 2.67 & 1.568 & 97.27 & 1.83 \\
\hline CH & 13.0 & 0.512 & 16.33 & 1.852 & 1.405 & 0.881 & 31.89 & 2.68 & 0.881 & 97.13 & 0.15 \\
\hline CL3 & 10.8 & 0.470 & 14.33 & 1.897 & 1.478 & 0.927 & 28.35 & 2.68 & 0.783 & 97.14 & 0.16 \\
\hline
\end{tabular}

(Legend: $c$ is the cohesion of the material, $\varphi$ is friction angle, $\gamma$ is volumetric weight of the soil, $\mathrm{CH}$ is clay high plasticity, $C L$ is clay low plasticity.)

Table 3: Summary of effected load (Source: results from the solution by SAP software)

\begin{tabular}{|c|c|}
\hline Maximum load & Long term load \\
\hline $\mathrm{V}=90.336 \mathrm{MN}$ & $\mathrm{V}=90.336 \mathrm{MN}$ \\
$\mathrm{M} x=103.6 \mathrm{MN} . \mathrm{m}$ & $\mathrm{M} \mathrm{x}=68.89 \mathrm{MN} . \mathrm{m}$ \\
$\mathrm{M} \mathrm{y}=51.56 \mathrm{MN} . \mathrm{m}$ & $\mathrm{My}=47.77 \mathrm{MN} . \mathrm{m}$ \\
$\mathrm{H} x=3.37 \mathrm{MN}$ & $\mathrm{H} x=2.92 \mathrm{MN}$ \\
\hline
\end{tabular}

(Legend: MN was Mega Newton)

\section{B. Calculation of pile}

Based on soil data and external loads, the pile was designed to be $20 \mathrm{~m}$ in length and $1 \mathrm{~m}$ in diameter. The ultimate bearing capacity of a single pile was, based on conventional solution, about $2.42 \mathrm{MN}$. If the load sharing by group of piles was about $75 \%$ the total load, the numbers of piles required for this foundation are about 28. The piles were distributed among all raft areas as in Figure 2. 


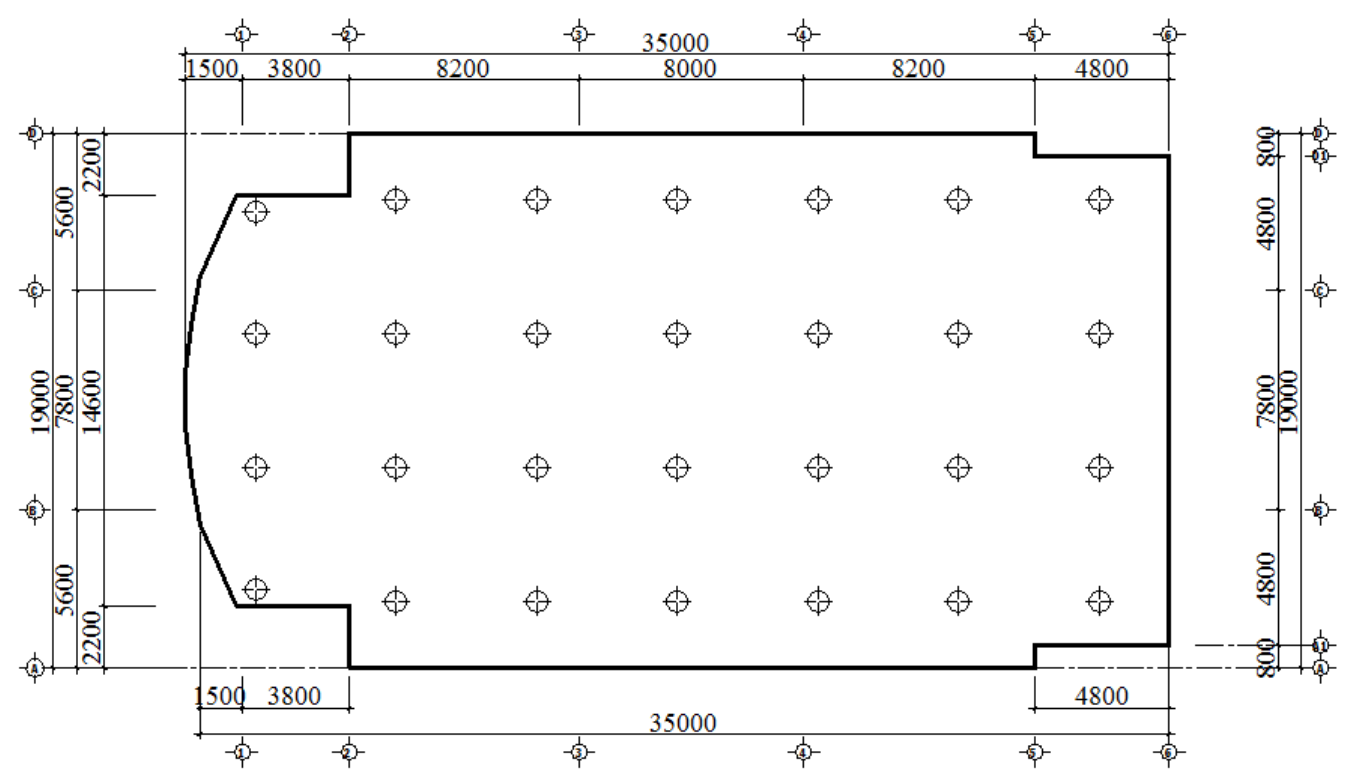

Fig. 2: Distribution of piles in piled raft foundation (mm)

\section{Calculation of piled raft}

The internal forces (moment and shear) of the raft were calculated by dividing the foundation into piled trips [7]. Figure 3 shows the method of calculation for internal forces of the raft. From conventional solutions, the total bearing capacity of the foundation was about $104.732 \mathrm{MN}$, and the uniform load of the building was $0.13583 \mathrm{MPa}$. Therefore, the load distributed on the top of each pile was about $2.42 \mathrm{MN}$. The average bearing pressure of the soil applying on the raft was about $0.034 \mathrm{MPa}$. Thus, a piled strip with $4.75 \mathrm{~m}$ in width and $35 \mathrm{~m}$ in length had a uniform load of $0.1615 \mathrm{MN} / \mathrm{m}$. The average uniform load of the building distribution on the piled strip was 0.6452 $\mathrm{MN} / \mathrm{m}$. Figure 4 shows the simplified model of piled strip for calculating the internal forces of the raft in a piled raft foundation.

\section{Groundwater pumping condition}

Similar to the method of calculation for a piled raft in normal conditions, this study also considered the case where the water level was lowered to an elevation of $-20 \mathrm{~m}$. The level of the water table in normal conditions was at ground surface.
Groundwater pumping conditions occurred when construction calls for deep excavation. The bearing capacity of a single pile was about 3.37 $\mathrm{MN}$, and the group of 28 piles was $94.36 \mathrm{MN}$. The unfavourable condition was when the soil under the raft did not make contact with the raft, and bearing pressure under the raft was zero. The load distributed on each pile was about 3.226 MN. Figure 5 presents the simplified model of a piled strip for calculating the internal forces of the raft in a piled raft foundation in groundwater pumping conditions.

\section{RESULTS AND DISCUSSION}

The internal forces (moment and shear) of the raft were calculated by the strip on spring method [7] which was plotted by Excel. The results based on Plaxis and SAP programs were also plotted for comparative purposes. The results of the analysis were presented from Figures 6 to 17. The moment and shear of the raft in normal conditions and in groundwater pumping conditions were shown in Figures 6 to 11 and in Figures 12 to 17 , respectively. 


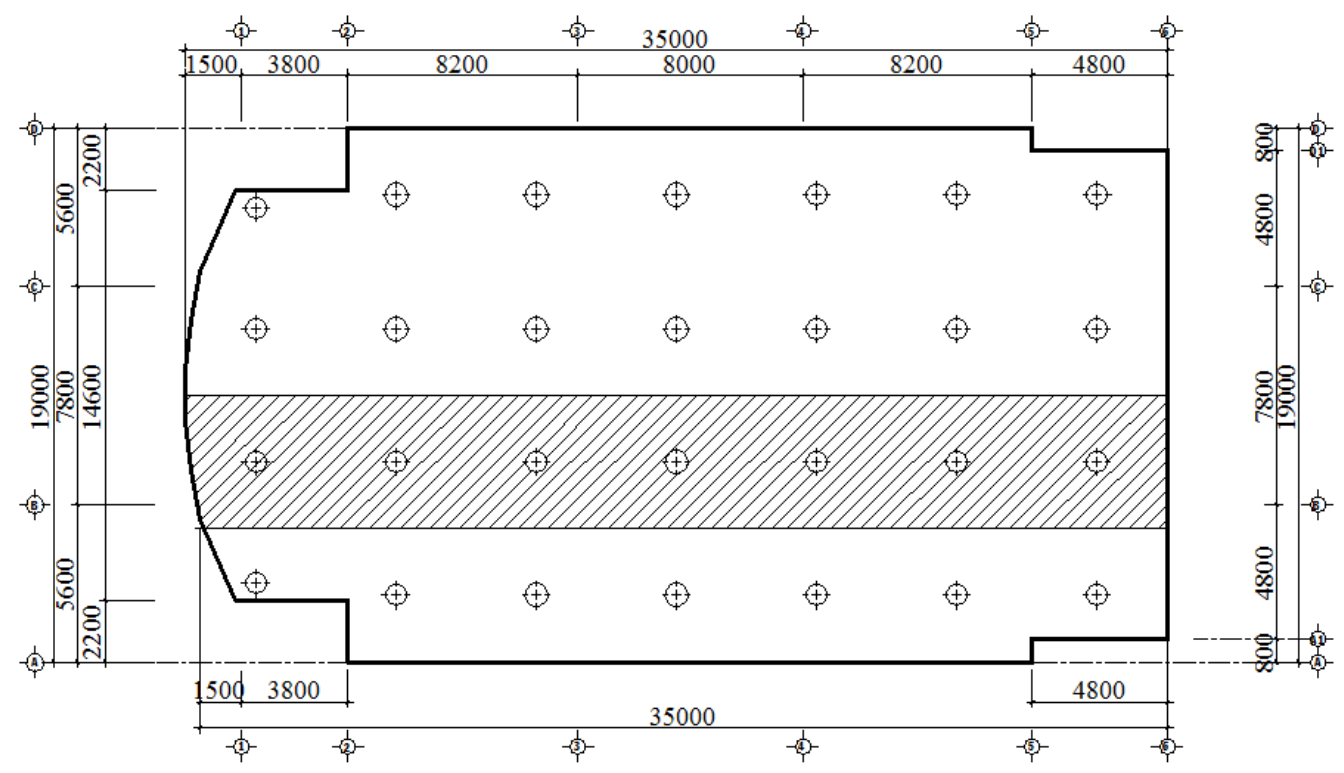

Fig. 3: Method of calculation for internal forces of raft (mm)

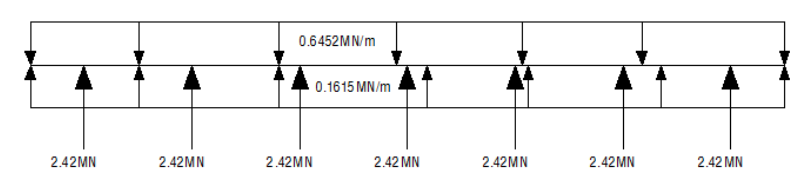

\begin{tabular}{l|l|l|l|l|llll}
$\mid 2500$ & 5000 & 5000 & 5000 & 5000 & 5000 & $\mid$ & 5000 & $|2500|$
\end{tabular}

Fig. 4: Simplified model of piled trip for calculating internal forces of raft $(\mathrm{mm})$

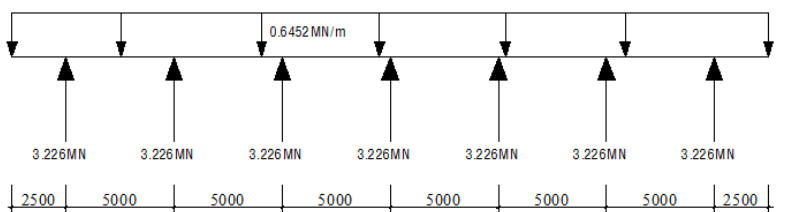

Fig. 5: Simplified model of piled strip for calculating internal forces of raft in piled raft foundation $(\mathrm{mm})$

For all figures, the horizontal axis (x-axis) was the length of the strip cutting from the raft, while the vertical axis (y-axis) was the values of moment or shear calculating from Plaxis, SAP, and Excel. The units of horizontal and vertical axes were meter $(\mathrm{m})$ and Mega Newton multiplied with meter (MN.m) for moment or Mega Newton
(MN) for shear force.

\section{A. Normal conditions}

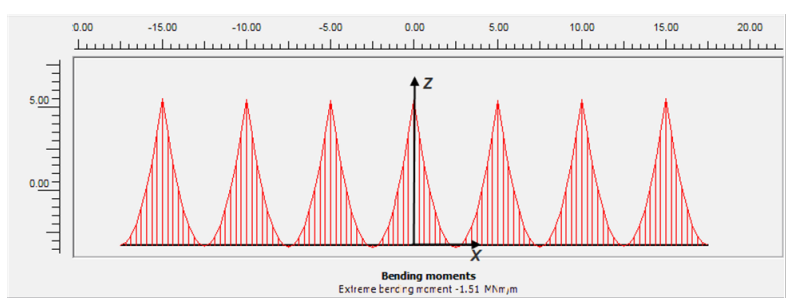

Fig. 6: Bending moments in x-direction (Plaxis 2D) (MN.m)

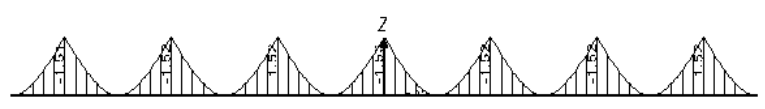

Fig. 7: Bending moments in $\mathrm{x}$-direction (Sap 2000) (MN.m) 


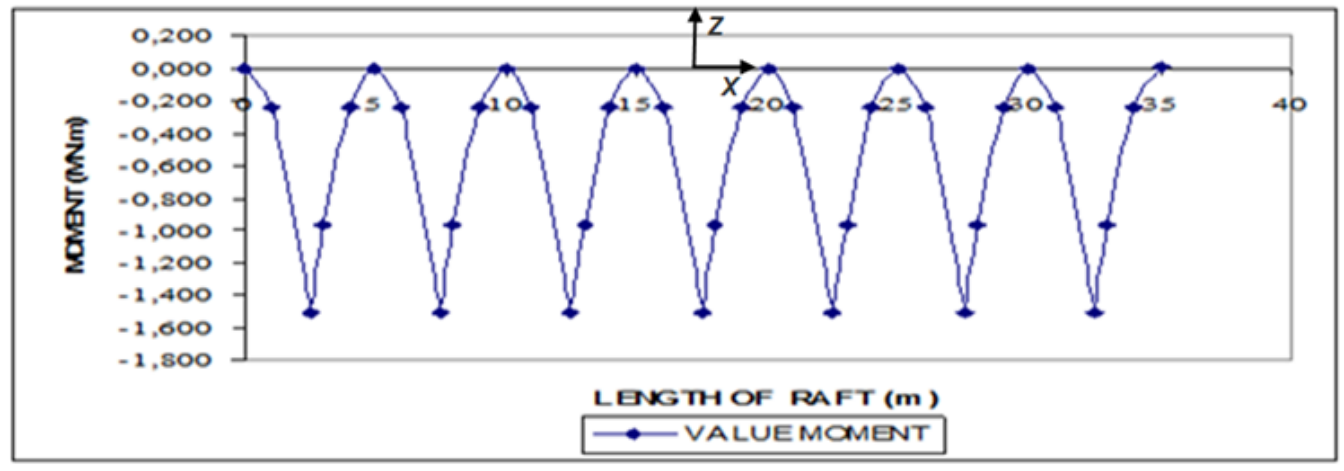

Fig. 8: Bending moments in x-direction (Excel) (MN.m)

Bending moment and shear forces of the raft determined by Plaxis, SAP, and Excel showed the same results. The bending moment was about 1.51 MN.m and shear force was about 1.21 MN. It shows that the analytical method of Poulos [7] was applicable for determining internal forces of the raft in a piled raft foundation.

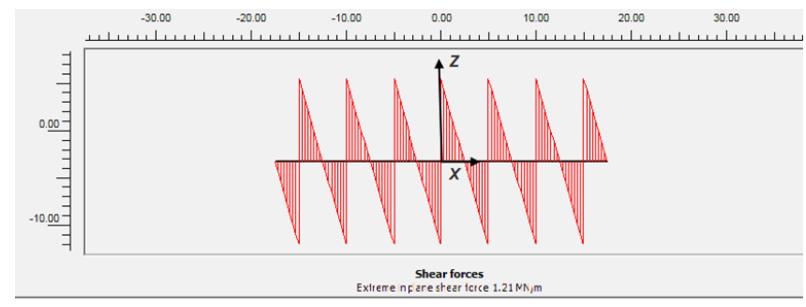

Fig. 9: Shear force of raft in $\mathrm{x}$-direction (Plaxis 2D) $(\mathrm{MN})$

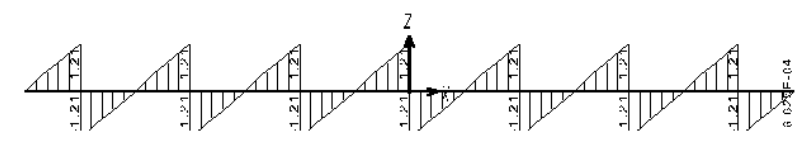

Fig. 10: Shear force of raft in $\mathrm{x}$-direction (SAP 2000) (MN)

\section{B. Groundwater pumping conditions}

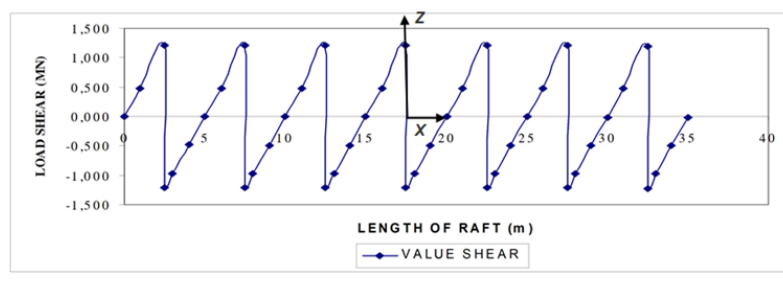

Fig. 11: Shear force of raft in $\mathrm{x}$-direction (Excel) $(\mathrm{MN})$

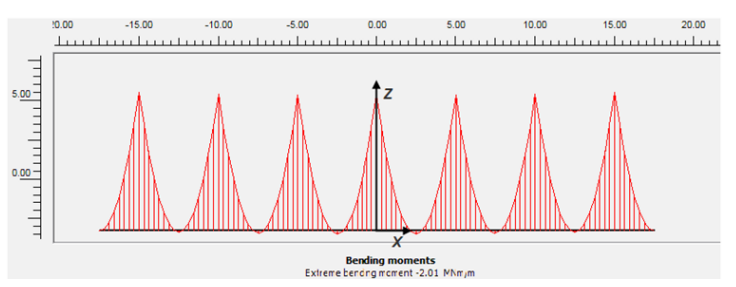

Fig. 12: Bending moments in $\mathrm{x}$-direction (Plaxis 2D) (MN.m)

In groundwater pumping conditions, both bending moment and shear forces of the raft increased. The values of moment and shear force were about $2.0 \mathrm{MN} / \mathrm{m}$ and $1.62 \mathrm{MN}$ respectively. The method of Poulos [7] was also applied for this case. 


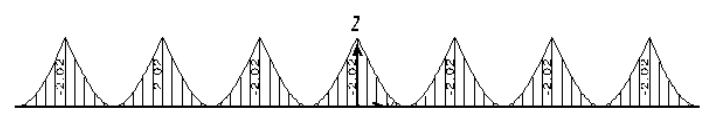

Fig. 13: Bending moments in $\mathrm{x}$-direction (SAP 2000) (MN.m)

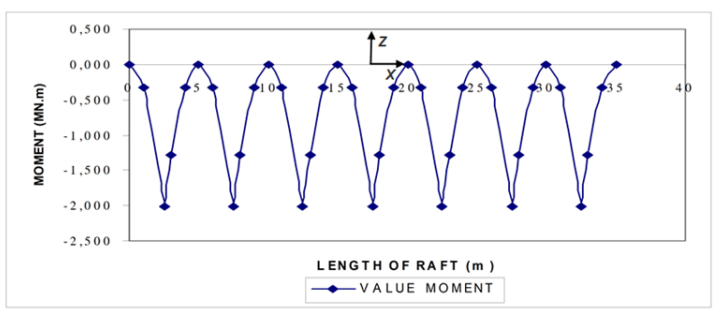

Fig. 14: Bending moments in $\mathrm{x}$-direction (Excel) (MN.m)

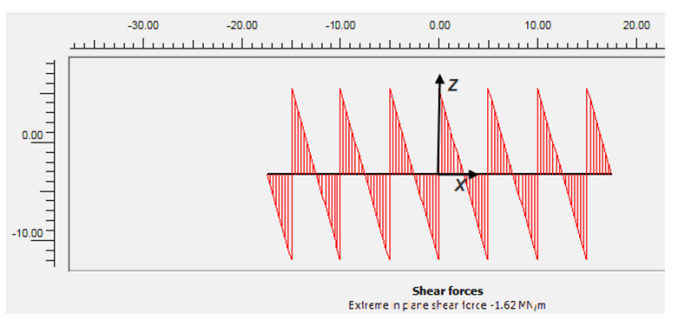

Fig. 15: Shear force of raft in $\mathrm{x}$-direction (Plaxis 2D) (MN)

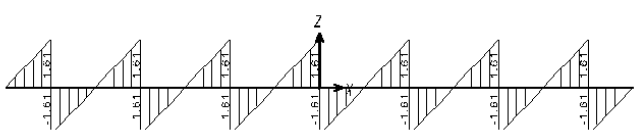

Fig. 16: Shear force of raft in $\mathrm{x}$-direction (SAP 2000) $(\mathrm{MN})$

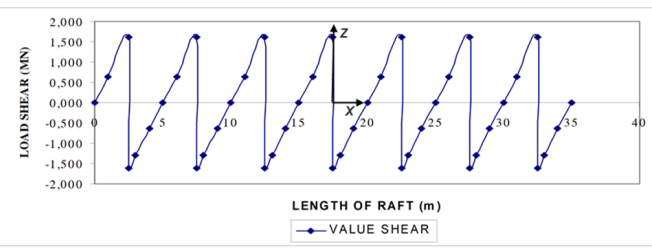

Fig. 17: Shear force of raft in $\mathrm{x}$-direction (Excel) (MN)

\section{CONCLUSIONS AND RECOMMENDATION}

Based on the results of this study, some conclusions were drawn out. The method in which the piled raft foundation was divided into several piled strips can be used for determining internal forces (moment and shear) of raft in piled raft.

In groundwater pumping conditions, internal forces of the raft were found to increase. Therefore, the incremental part of internal forces of the foundation should be considered in design when groundwater pumping condition occurred in the project. Internal forces determined by Plaxis, SAP and Excel showed the same results. It shows that the analytical method of Poulos [7] was applicable for determining internal forces of the raft in a piled raft foundation. Finite element method can be used to determine the internal force due to groundwater pumping. It was found that during the survey, construction designs need to calculate the lowering level of the groundwater to consider the possibility of constructing a piled raft foundation.

Sustainable management strategies should be developed to deal with groundwater exploitation by the legal text, and plan to use groundwater storage reasonably to avoid drawdown. More research works including experimental tests and FE analysis for piled raft in ground subsidence condition are recommended for further research. The research should also be focused on 4 types of interaction between raft, piles, and soil which are of major importance in the behavior of piled rafts.

\section{REFERENCES}

[1] Wagner F, Tran V B, Renaudk F G. Groundwater resources in the Mekong Delta: availability, utilization and risks ed F G Renaud and C Kuenzer. Dordrecht: Springer; 2012.

[2] Erban Laura. E, Steven M Gorelick, Howard A Zebker. Groundwater extraction, land subsidence, and sea-level rise in the Mekong Delta,Vietnam. Environmental Research Letters. 2014; 9:1-6.

[3] Phung Duc Long. Piled raft - A new foundation design philosophy for high rises. Geotechnics for Sustainable Development - Geotec Hanoi, Phung (edt). Construction Publishing House. 2011. ISBN 978604-82-000-8.

[4] Hemsley J. A. Design applications of raft foundations. London: Thomas Telford; 2000. 
[5] Randolph M. F. Design methods for pile groups and piled rafts. State of the Art Report Proc, ICSMFE. 1994; 5:61-82.

[6] Poulos H. G. Piled raft foundation: "design and applications". Geotechnique. 2001; 51 (2):95-113.

[7] Poulos, H. G. Analysis of pile strip foundation. In G. Beer, Booker \& Carter (eds). Computer methods and advances in Geomechanics. Balkema, Rotterdam; 1991; 183-191.

[8] RBJ. Brinkgreve, WM. Swolfs, E. Engin, D. Waterman, A. Chesaru, P. Bonnier, V. Galavi. Plaxis user's manual, version 2.0. Rotterdam: Balkema; 2007.

[9] Computer and Structure, Inc. SAP2000 Manuals. Berkerley, California, USA; 2000.

[10] Das B. Principles of foundation engineering. PWSKent-Boston; 1999.

[11] E.E de Beer. Experimental determination of the shape factors and the bearing capacity factors of sand. Geotechnique Journals. 1970; 20(4):387-411.

[12] G.G. Meyerhof. Some recent research on the bearing capacity of foundations. Can. Geotech. J. 1963; 1 (1): $16-26$

[13] A.M. Hanna, G.G. Meyerhof. Experimental evaluation of bearing capacity of footings subject to inclined loads. Canadian Geotechnical Journal. 1981; 18(4):599-603.

[14] Huynh Hong. Report results of construction geological survey in the area of Soc Trang province. Duy Thanh Construction and Environment consulting joint stock company of Tra Vinh province; 2010. 